\title{
PREGNANCY MYTHS IN PETANG SUB DISTRICT, BADUNG, BALI
}

\author{
Mastiningsih Putu, Doctoral Student of Culture Studies \\ Udayana University, Indonesia \\ E-mail: mastiningsihputu@yahoo.com
}

\begin{abstract}
This research was done to understand pregnancy myths in Petang Sub District, Badung, Bali. This research background was the inequality between assumption and reality in field. Ideally, society in this global era will prefer and believe medical treatment for pregnant women. But the reality is different. They believe myths more than medical treatments. The questions were: (1) What are the myths of pregnancy in Petang Sub District, Badung?; (2) What is the ideology between those myths?; and how do the society interpret those myths?This research method was qualitative method. Primary data source was supported by secondary data. The data was collected by observation, interview, forum group discussion (FGD), and literature study. The data was reviewed in cultural study perspective and analyzed with critical theories. The research results showed that: (1) the form of pregnancy myths in that sub district are passed in form of oral tradition, such as prohibitions and suggestions to consume food and drinks, acts, and ritual ceremonies from pregnancy until the baby is born; (2) Ideology between those myths is prevention from pregnancy risks, safety, health, and religion ideology; (3) Those myths are sustainable because they have safety meanings, keep the family relationship, health education, and cultural conservation.
\end{abstract}

\section{KEY WORDS}

Ideology, myths, pregnancy, mythical meaning, Bali; culture.

Indonesia is a multi-ethnical country that has various traditions and unique culture as the society's adaptation in solving their daily life's problems. Besides the behavioral habits and life equipments, there are also myths as belief that can protect them from problems in life. In ideal level, culture can be viewed as ideas, thoughts, values, norms, and rules. As ideal form of those cultures, the society then takes them as the guideline to organize their behavior in life (Danandjaya, 2002).

There is an element that have more specific characteristic than the cultural value system, called ideology concept and myth (Alawiyah, 2009). As a multi-ethical country, Indonesia has ideology and myths related to various aspects of life, such as politics, women's life, sex, and also pregnancy myths (Barthes, 2007).

Myth is a form of belief that is assumed to be true (Barthes, 2003). Until now, there are still many myths in Indonesia. Those myths are various, corresponding to the customs of every region (Argawa, 2007). Myths in Java will be different with those that developed in Bali. Some research showed that Indonesian people are still thick with supernatural or mythical things (Barthes, 2007; Danandjaya, 2002; Rafi, 2009).

People in Petang Sub District, Badung, Bali, are still using the myths to treat pregnant women. Based on the myth, pregnant woman are vulnerable to be disturbed by evil spirits. Therefore, pregnant women must perform some rituals and use an amulet to be spared from evil spirit's disturbance (Argawa, 2007). People in Petang Sub District, Badung, Bali, used the myths to keep the health of pregnant women. This can be seen from their obedience to those myths. Their belief is so strong towards those myths, and even become their cognitive maps that local pregnant women should know and obey the pregnancy myths. This means that pregnancy myths are thought to be a knowledge that should be known and obeyed in order to be safe from miscarriage. The myths are believed by the society as natural knowledge (Barthes, 2007).

In this global era, people's belief in Petang Sub District, Badung, Bali, to pregnancy is interesting to be studied. Critical study about this topic will lead us to the meanings behind 
the cultural phenomena. The background of this study is the inequality between assumption and reality in the society. Ideally, society in this global era will prefer and believe medical treatment for pregnant women. But the reality is different. They believe myths more than medical treatments. From this background, some questions could be raised: (1) What are the myths of pregnancy in Petang Sub District, Badung?; (2) What is the ideology between those myths?; and how do the society interpret those myths?

\section{METHODS OF RESEARCH}

This research was done by qualitative research method. Primary data source was supported by secondary data from related research results. The data was collected by observation, interview, forum group discussion (FGD), literature study, and documentation technique. Those techniques were used in order to find the meanings of pregnancy myths to people in Petang Sub District, Badung. For example, symbols and problems are solved by group discussion. Group discussion technique was used to reveal the perception about pregnancy myths phenomena. Information from the discussion were then collected to reveal or answer the perceptions about perception, group attitude, and group decision of pregnancy myths. All collected data were then critically analyzed by using deconstruction theory, mythology theory, and semiotics theory.

\section{RESULTS OF RESEARCH}

The Form of Pregnancy Myths in Petang Sub District, Badung, Bali. Based on data analysis, it could be understood that the form of pregnancy myths in Petang Sub District, Badung, Bali, are passed through oral tradition. Oral tradition is an institutionalization process of cultural values, which is orally and hereditary transmitted (Pudentia, 1998). Pregnancy myths in Petang Sub District are in form of prohibitions and suggestions to consume food and drinks, acts, and ritual ceremonies from pregnancy until the baby is born. Some of those prohibitions and suggestions are subject to the pregnant women, and some of them are subject to the husband. Prohibition myths for pregnant women are such as not to consume some food like durians, pineapples, pakel mangoes, strawberries, salak, and watermelons.

Local people believed that if pregnant women disobey that myth, they will experience unfortunate thing like miscarriage. To prevent that, the elderly of Petang Sub District appealed that pregnant women should keep their health by obeying the myths believed by the people. Various guidelines about pregnant women's health were also stated that in order to make the developing baby healthy, the mother should consume healthy foods (Emmas, 2001; Dalimartha et al., 2001: Sutomo et al., 2010).

Besides prohibitions to consume some fruits, there are also myths of suggestion to consume the meat of cerucukkuning bird and murai or kedisbecica bird. Chicken's liver, green beans and bean sprouts are also suggested foods to consume. Local people believed that if pregnant women consume the birds' meat, green beans (Vigna radiate), and bean sprouts (Phaseolusaureus), the developing baby will grow healthy, smart, and has thick hair. Some beverages were also prohibited to drink, such as carbonated soft drinks, alcohol, iced water, and large amount of water. Local pregnant women named Mrs. PutuPuspa said that if that myth is disobeyed, the baby will not develop normally.

People in Petang Sub District were also having myths in form of ceremony rituals and prayers. A pregnant woman is suggested to always pray and ask for their safety, in orders to be guarded and has peaceful soul. Pregnant women is suggested to do melukat, taking a bath with water and flowers during full moon. Besides that, pregnant women is suggested to do pangerujakan and pagedong-gedongan ceremonywhen their pregnancy reach 5 months old. Those ceremonies are believed to make the pregnant women's soul become peaceful and the baby become a good and responsible child.

Ideology behind Pregnancy Myths. Essentially, ideology is formed through reciprocity that furthermore legitimate political dominance, identity, beliefs, action orientations, and 
systemic communication distortion in ideological domain of people (Jorge, 1996). Ideological perspective is identical to people's collective perspective, as well as people in Petang Sub District that view the importance of pregnancy myths to be done in this global era. Ideology in every people's thoughts in that area will direct their action collectively. Through language and action, ideology is socialized and spread by the elderly as social reality in that area. In relation to pregnancy myths, traditionally the treatment of pregnant women was done by customary abstinence and suggestions according to Balinese cultural value. According to LontarEkapratama, it was mentioned that the fetus is assumed to be surrounded by its siblings (nyamacatursanak). This can be illustrated in Figure 1.

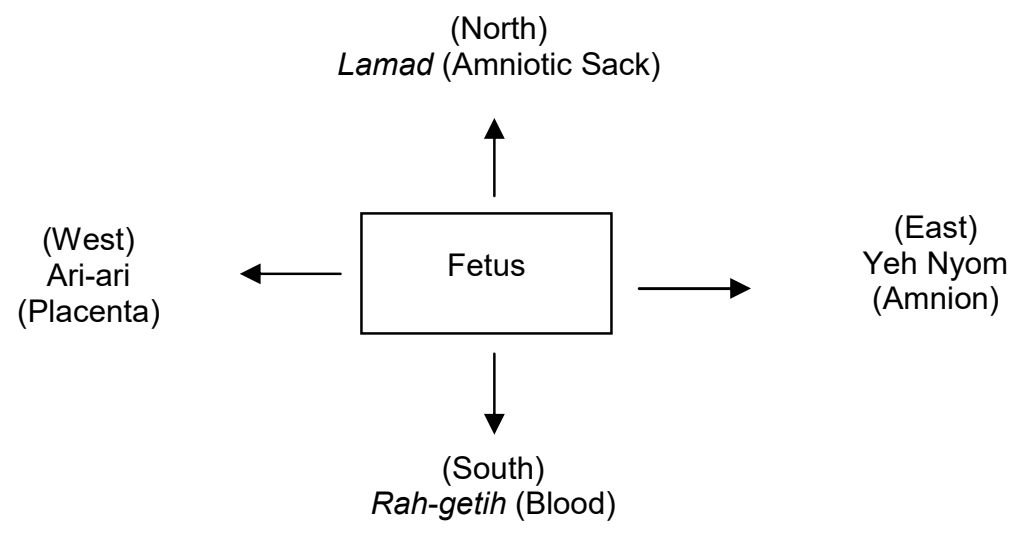

Figure 1 - NyamaCaturSanak as One of Balinese Belief

According to Kanda Pat Rare, it was explained that the fertilization between kamaputih (sperm) and kama bang (egg cell) will produce purusa-pradana. In the first month, it is in the form of sun and moon. In the second month, it is in the form of bayu, sabda, and idep. In the third month, it is in form of Umanis - Pahing - Pon - Wage - Keliwon (Pancawara) or pancendriya. The fourth month is the meeting of DewataNawaSanga. In the fifth month, the arth and sky (Akasa) meets to become the fetus, called "PuntiMaha-yanti". In the sixth until ninth month, will be born: BabuLembana, BabuAbra, BabuUgian, and BabuKakered (CaturSanak or four siblings). They have a shared meaning from the holy water from "SindhuRahasiaMuka". In the tenth month, the baby will be born with his/her siblings, Sang Anta (placenta), Sang Preta (umbilical cord), Sang Kala (blood), and Sang Dengen (yehnyom / amniotic fluid).

The baby will then ask for help to Sang CaturSanak, to get him/her out of the mother's womb. The first is to the yehnyom (amniotic fluid), to open the way from the front. The second is to rah (blood) to open it from the right. The third is to the placenta, to open it from the back. The last to the lamad (amniotic sack) to open it from the left.After all the way is open, then ragasarira (ourselves) can pass. Sang CaturSanak agreed to help the baby, with one condition that after the baby is born, the baby should not forget them. If the baby forgets the four siblings (Sang CaturSanak), they will not help the baby anymore whenever he/she meets a trouble. The baby agreed with that condition, and after made a deal with Sang CaturSanak, the baby is ready to be born to the challenging world. Yehnyom open the way, blood gives the strength, lamas gives lubricant, meanwhile the placenta and umbilical cord push the baby out. By the cooperative work of Sang CaturSanak, the baby born perfectly to the mysterious world and life (Tonjaya, 1989). This explanation was based on LontarEkapratama. Meanwhile, the medical perspective mentioned that the process of pregnancy begins after the conception (fertilization) until the baby is born (Meilasari, 2006).

Pregnancy is the period that begins after the fertilization in women's uterus until the baby is born (Bahiyatun, 2009). Pregnancy may occur when a women has sex in her fertile period (when the ovary produces a mature egg cell), and the sperm of her partner fertilize her egg cell (Candra, 2009). Fertilized egg cell will attach itself to the uterine wall, and then it 
will grow and develop until approximately 40 weeks (280 days) in normal condition (Wiknjosastro, 2002).

Blood (rah-getih) or hemoglobin/Hb is metalloprotein (protein that consist of iron) in red blood cells that have function to carry oxygen from the lungs to the whole body and also to carry carbon dioxide back to the lungs and exhaled out of the body (Leveno, 2009).

According to $\mathrm{WHO}$ data, the level of $\mathrm{Hb}$ can be classified into three levels: normal $(>11$ $\mathrm{g} / \mathrm{dl})$, mild anemia (8-11 $\mathrm{g} / \mathrm{dl})$, and severe anemia $(<8 \mathrm{~g} / \mathrm{dl})$. Placenta consists of more than 200 or more blood vessels and delicate veins; its form is resembled to raw liver (Neu, 2007). The maternal side that attach to the uterus appears rough and hollow. It has deep red color and divided into 15-20 cotyledon bulges, which are villi or fingerlike protruding. The fetus' surface is so delicate, and the umbilical cord is usually in the center. A mature placenta has flat disc-like shape (Tripathy, 2014). It weighs approximately 500 grams, $20 \mathrm{~cm}$ or 8 inches in diameter, and 2,5 cm or 1 inch of central thickness. The size and the weight of placenta is various according to the size of fetus. Placenta is usually located on the top part of uterus, but if it is located in the bottom part it is called placenta previa. Placenta's function is to deliver nutrients and oxygen from mother's blood to fetuses, and also to carry back carbon dioxide and waste from the fetus to the mother's blood (Macdogall, 2003). This can be illustrated in Figure 2.

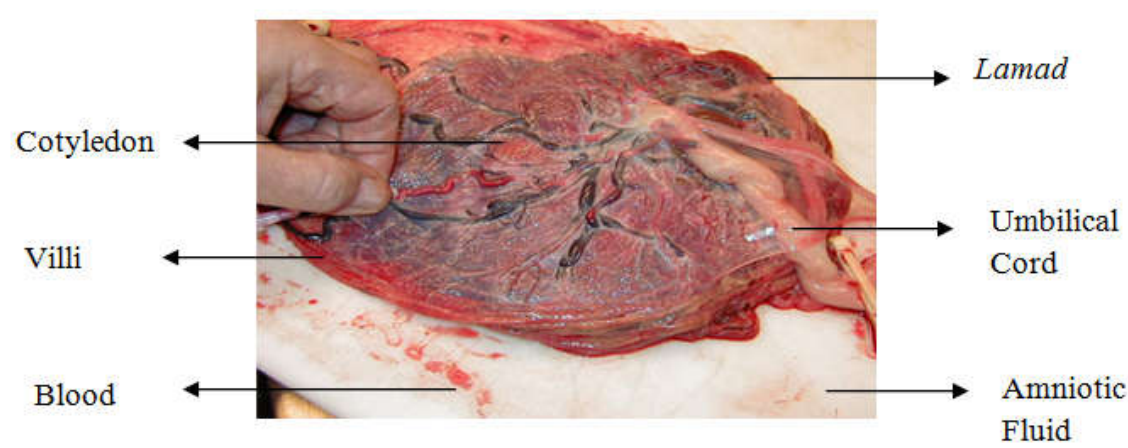

Figure 2 - Placenta

Figure 2 shows a placenta. Amniotic sack (lamad) is a membrane that protects the fetus during the pregnancy. This membrane originates from the mother's body part and the fetus' part. Disturbance in amniotic sack such as chorioamnionitis may be dangerous for both the mother and the baby. Pregnant women in Petang Sub District believe that to prevent the risks of pregnancy disturbances they should obey the myths.

After the baby born, people in Petang Sub District assumed that boys are considered as important and he will be responsible in sustaining the generations. Meanwhile, girls will leave after she gets married, but will be replaced by other girl as wife so that it remains balance. The patriarchy history forms human civilization that viewed boys as the more powerful (superior) than girls in private, family, society, and country life.

According to Lontar Kuna Drsti and Pula Kerti, the ManusaYadnya ceremony could not be held before the pregnancy reach 5 months old. A month in Balinese month is 35 days. In other words, ManusaYadnya or Pagedong-gedongan ceremony can be held if the pregnancy has reach 5 months or more. Difficult delivery is believed by the people to be neutralized by Sapuh Leger, a ceremony or ritual in which traditional puppet or wayang is performed.

The Meanings of Pregnancy Myths in Petang Sub District, Badung, Bali. Until this day, pregnancy myths remain sustainanble in Petang Sub District, Badung. This is because the people in that area believed that the pregnancy myths are important and beneficial to their lives. The pregnancy myths in Petang Sub District, Badung are used as the guidelines to treat pregnancy.

Meanings are formed through the knowledge and experience of local people, and then they are internalized (Clair and Anderson, 1989). Some experts had reviewed meanings by various methods and theories according to their own disciplines. Meaning is revealed and 
discussed by understanding various signs in normal society life, called semiotics (Hoed, 2008). Everything that appears in life can be seen as a sign. The human thoughts can be realized as an activity and life signs (talking, working, eating, drinking, and any other activity) are understoodas a meaning. Saussure saw those signs as the meeting of illustrations in someone's cognition, and meanings can be understood as the use of signs (Hoed, 2008).

The meanings of pregnancy myths in Petang Sub District, Badung are mostly the same as other people's meaning in Bali. But, the meaning that developed in Petang Sub District had relevance with the condition of natural environment and religion system of the local people. The relationship between people's meanings and those two aspects made the meanings of pregnancy myths in that area remains exist although modern medications had entered that area.

In order to prevent pregnant women from having pregnancy problems, people in Petang Sub District obeyed the prohibitions related to pregnancy. Prohibitions and suggestions to consume foods and drinks for pregnant women are various, such as pregnant women should not consume pineapples and durians. If pregnant women consume those fruits, they believe that it will endanger the baby's safety. A pregnant woman is believed to have miscarriage or premature birth if they consume pineapples and durians. That can be understood medically, because pineapples and durians contain high amount of alcohol and that can disturb the baby's health. Those prohibitions related to pregnancy had been explained by Suwigno and Fitria (2010) and Tino (2009).

Although the gender theory had stated that this time human evolution had been on parental level, but the reality showed that family hegemony in Petang Sub District still occurs. Harmonic family relationship in Petang Sub District are often be related to the attitude and tolerance of a daughter-in-law to the values and norms in that place. Pregnancy myths are often be used as a measure in assessing a daughter-in-law (Gillespie, 2013). The more violations to the myths, the more misunderstandings will occur between a daughter-in-law and a mother-in-law. And the more obedience a daughter-in-law to the myths, then the more harmonic the relationship will be.

Pregnancy myths are commonly related to customary abstinence, consumption and action suggestions. Those myths are already existed long time ago (Barthes, 2003). Myths are transferred through non formal education in family (Rafi, 2009). The sustainability of the myths containing values and norms is a continuum of long process (Jorge, 1996). Education process in every family starts after the baby recognizes the nearest environment (family), and then when he begins to recognize societal environment, until he understand the values and norms in his cultural environment (Argawa, 2007).

Tradition is a custom or repeated action, shaded by the customs that contain normative value (Danandjaya, 2002). In the Petang Sub District, there are many myths that should be obeyed by pregnant women in order to keep the mother and baby healthy. The myths are sustainable because they are assumed to be beneficial in life, so they must be used and obeyed. According to the local people, by following the myths their minds are in peace. Meanwhile, the modern pregnancy treatment will also make the mother and baby healthy. This had caused the sustainability of pregnancy myths in Petang Sub District.

\section{CONCLUSION}

Based on the explanation, it can be concluded that the form of myths in Petang Sub District, Badung, Bali, were passed in form of oral traditions, which are prohibitions and suggestions to consume foods and drinks, actions, and ritual ceremonies from the early pregnancy period until the baby is born.

Ideologies between pregnancy myths are:

Prevention ideology from the pregnancy risks that implemented in form of various customary abstinences and suggestions to consume foods and drinks, and ethical actions according to Balinese cultural values. People saw pregnancy as a very important period and vulnerable to miscarriage threat so that the safety of both mother and baby should be kept by implementing the myths. 
Mother and baby's safety ideology. People in Petang Sub District believed that obedience to the customs throughout the pregnancy will have a big effect on the mother and baby's safety.

Religion ideology. People in Petang Sub District had implemented the myths by doing ritual ceremonies related to the threats (magic) that may happen. The ceremonies are Pangrujakan, Pagedong-gedongan, traditional puppet (wayang) performance of Sapuh Leger, and Mebayuh. They believe that those ceremonies will make the baby grows healthy and strong.

People in Petang Sub District keep sustaining the myths because they think that pregnancy myths are meaningful to the mother and baby's safety, meaningful as family relationship keeper, and meaningful as cultural conservation. Tradition is a custom or repeated actions shaded by customs that contain normative values. Those myths are well maintained because they give benefits to people's lives, so that they will always being followed and obeyed.

\section{REFERENCES}

1. Alawiyah, S. 2009. "Dinamika Keyakinan Ibu Hamil Terhadap Mitos-Mitos Kehamilan". (Tesis).Malang : Universitas Negeri Malang.

2. Argawa, I.N. 2007.Fungsi dan Makna Mitos Dewi Anjani Dalam KehidupanMasyarakat Sasak.(Tesis). Denpasar : Universitas Udayana.

3. Bahiyatun.2009. Buku Ajar Asuhan Kebidanan Nifas Normal.Jakarta: EGC.

4. Barthes, R. 2003. Mitologi.Terjemahan Critian Ly dari Mythologies.Padang: Dian Aksara Press.

5. Barthes, R. 2007. Membedah Mitos-Mitos Budaya Massa. Yogyakarta: Deepublish

6. Candranita, M.I.A. 2009.Memahami Kesehatan Reproduksi Wanita Edisi 2. Jakarta: EGC.

7. Clair, P.A.S., \& Anderson, N. A. (1989). Social network advice during pregnancy: Myths, misinformation, and sound counsel. Birth, 16(3), 103-107.

8. Dalimartha, Setiawan \& Adrian, F. 2011.Khasiat Buah \& Sayur.Jakarta: Penebar Plus.

9. Danandjaya, J. 2002. Folklor Indonesia, IImu Gosip, Dongeng, dan lain-lain. Jakarta: Pustaka Utama.

10. Emmas, W. 2001.Gizi pada Ibu Hamil dan Menyusui.Jakarta: Kencana.

11. Gillespie, S. (2013).Myths and realities of child nutrition. Economic and Political Weekly, 48(34), 64-67.

12. Hoed, B.H.2008.Semiotika dan Dinamika Sosial Budaya.Jakarta : Fakultas IImu Pengetahuan Budaya Universitas Indonesia.

13. Jorge, L. 1996.Konsep Ideologi. Penerjemah Ryadi Gunawan. Yogyakarta: LKPSM.

14. Leveno, K.J. 2009.Obstetri Wiliams, Panduan Ringkas. Jakarta: EGC.

15. Macdogall, J. 2003.Kehamilan Minggu Demi Minggu. Jakarta: Erlangga.

16. Meilasari,M.2016. AsuhanPersalinanNormal. Jakarta: Puspaswara.

17. Neu, J. (2007). Myths and dogmas in neonatal gastroenterology and nutrition.NeoReviews, 8(11), e485-e490.

18. Pudentia.1998. Metodologi Kajian Tradisi Lisan. Jakarta : Yayasan Obor Indonesia dan Yayasan Asosiasi Tradisi Lisan.

19. Rafi, T. 2009. Menjawab mitos-mitos kehamilan dan menyusui.Yogyakarta: Media Pressindo.

20. Sutomo,Budi \& Yanti, A.D. 2010. Makanan Sehat Pendamping ASI. Jakarta: Agro Media Pustaka.

21. Tino, R.A. 2009. Menjawab Mitos-Mitos Kehamilan dan Menyusui.Yogyakarta: Media Presindo.

22. Tonjaya K. 1989. Kanda Pat, Denpasar: Ria.

23. Tripathy, S.N. (Ed.). (2014). Nutrition and Pregnancy-ECAB.Elsevier Health Sciences.

24. Wiknjosastro, H. 2002. Ilmu Kebidanan. Jakarta: Yayasan Bina Pustaka Sarwono Prawirohardjo. 